\title{
SYNTHESIS, ANTI-PHYTOPATHOGENIC AND DPPH RADICAL SCAVENGING ACTIVITIES OF C-PRENYLATED ACETOPHENONES AND BENZALDEHYDES
}

\author{
MAURICIO E. OSORIO ${ }^{*}$, KAROL A. QUIROZI, MARCELA A. CARVAJAL', ALEJANDRA P. VERGARA', \\ ELIZABETH Y. SÁNCHEZ $Z^{2}$ CESAR E. GONZÁLEZI AND KAREN S. CATALÁN ${ }^{1}$
}

\author{
${ }^{1}$ Laboratorio de Productos Naturales, Departamento de Química, Universidad Técnica Federico Santa María, Valparaíso 2390123, Chile. \\ ${ }^{2}$ Centro de Biotecnología CB-DAL, Universidad Técnica Federico Santa María, Valparaíso 2390136, Chile.
}

\begin{abstract}
The syntheses of six prenylated acetophenone and benzaldehyde derivatives and their anti-phytopathogenic and antioxidant activities are reported. These compounds were obtained by electrophilic aromatic substitution $\left(\mathrm{S}_{\mathrm{E}} \mathrm{Ar}\right)$ of the corresponding arenes and 3-methyl-2-buten-1-ol using $\mathrm{ZnCl}_{2}$ as a Lewis acid catalyst in ethyl acetate. Reasonable to good yields were obtained based on unrecovered aromatic starting material (45-73\%). All the synthesized compounds were evaluated against phytopathogenic gram-negative bacteria Agrobacterium tumefaciens, Pseudomonas syringae and Erwinia carotovora and plant fungal pathogens Botrytis cinerea, Phytophthora cinnamomi and Gibberella fujikuroi. The antioxidant activity was evaluated using the 2,2-diphenyl-1-picrylhydrazyl (DPPH) radical scavenging activity assay and expressed as half maximal inhibitory concentration $\left(\mathrm{IC}_{50}\right)$ values in $\mu \mathrm{M}$ concentrations. The antioxidant activity went from $27.20 \mu \mathrm{M}$ to $>100 \mu \mathrm{M}$. Compound $\mathbf{1 1}$ showed statistically significant inhibition of the growth of Botrytis cinerea, and compounds $\mathbf{1 3}$ and $\mathbf{1 5}$ showed statistically significant inhibition of the growth of Phytophthora cinnamomi, with respect to negative control fungal growth. All six compounds showed bacteriostatic effects against gram-negative plant pathogenic bacteria with $\mathrm{IC}_{50}$ values between 250 and $<3.9 \mu \mathrm{M}$.
\end{abstract}

Keywords: C-prenylation; prenylated acetophenone; prenylated benzaldehyde; electrophilic aromatic substitution; anti-phytopathogenic; DPPH radical scavenging activity.

\section{INTRODUCTION}

Acetophenones and benzaldehydes are versatile molecules and are widely used as precursors to other natural products such as flavonoids. Prenylated acetophenones have been found in diverse plant materials. Recent examples of prenylated acetophenones are 1, isolated from the root bark of Derris indica, a South Asian medicinal plant ${ }^{1}$, and the antinociceptive and gastroprotective 3,5-diprenyl-4-hydroxyacetophenone 2 from Ageratina pichinchensis ${ }^{2}$. The prenylated benzaldehyde montadial A $\mathbf{3}$ was isolated from the white rot fungus Bondarzewia montana that grows at the base of Abies and other conifers, and showed strong cytotoxic activity against L1210 (murine lymphocytic leukemia) as well as HL60 (promyelocytic human leukemia) tumor cells (Figure 1). Harronin I, a prenylated acetophenone, showed a MIC of $5 \mu \mathrm{g} / \mathrm{mL}$ against $C$. albicans, $6 \mu \mathrm{g} / \mathrm{mL}$ against $B$. cereus and more than $20 \mu \mathrm{g} / \mathrm{mL}$ against other tested microorganisms ${ }^{4}$.
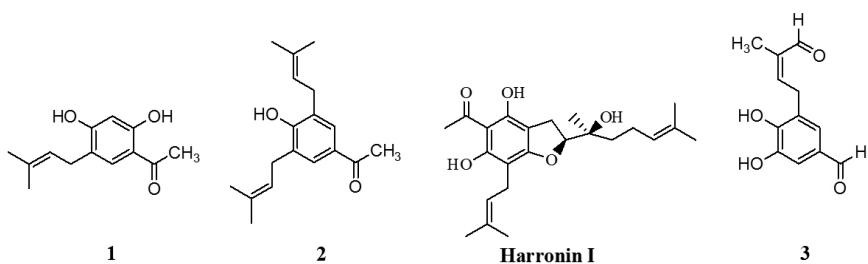

Figure 1. Representative structures of natural prenylated acetophenones $(1,2$, Harronin I) and benzaldehyde (3).

Fungal plant pathogens such as Botrytis cinerea, Phytophthora cinnamomi and Gibberella fujikuroi attack a wide range of agriculturally and ornamentally important plants ${ }^{5}$ and significantly affect the economy of developing countries causing large economic losses in agriculture ${ }^{6}$.

Botrytis cinerea is a fungus that affects many species of plants causing necrotic injuries in different plant tissues ${ }^{7}$. Gibberella fujikuroi is a filamentous fungus that causes the disease called "bakanae" in rice and other grasses; it is characterized by excessive growth of the plant and a reduction in the size and quality of the fruit, caused by the excessive production of the plant growth hormone, Gibberellin $\mathrm{GA}^{8}{ }^{8}$. Phytophthora cinnamomi is a phytopathogenic fungus that causes the disease "avocado root rot" and is the main phytosanitary problem of this fruit in Chile 9 . Excess moisture in the soil and root wounds create favorable conditions for this fungus ${ }^{10}$. Numerous treatments are used to control fungal phytopathogens, among others carboxin, captan, thiram, tebuconazole, metalaxyl, all of which pose a certain degree of danger. Further, in Chile, the highly toxic methyl bromide and other pesticides have been used to control B. cinerea in berries. Although pesticides are designed to control pests, they are also environmental poisons, affecting humans as the final consumers. A few years ago, Chile banned the use of methyl bromide under the Montreal Protocol ${ }^{11}$ and limited the use of pesticides based on recommendations from the Codex Alimentarius specifying the maximum residue limits (MRLs) for residues of pesticides or veterinary drugs in foods ${ }^{12}$.

Plant diseases caused by plant pathogenic bacteria are major problems for industrial agriculture in Chile because they affect plants of nutritional and commercial interest. Agrobacterium tumefaciens, Pseudomonas syringae and Erwinia carotovora are Gram-negative bacteria and are responsible for a number of economically important diseases in the Pacific Northwest and Southwest of the USA. These bacteria can infect a wide range of fruits, vegetables, and ornamental plants ${ }^{13-15}$. A variety of methods have been tested for the control of A. tumefaciens, $P$. syringae and E. carotovora in commercial plantings. However, the results of these control efforts have not always been successful. This gives rise to the need for new, less toxic products to replace the existing ones. Currently, the worldwide trend is to explore new alternatives to synthetic fungicides and bactericides in order to minimize the risks associated with the development of pathogen populations insensitive to these chemical compounds. At the moment, our research group investigates alternatives that are safer than the antiphytopathogens in current commercial use.

In general, terpenylphenols are isolated in very low yields from natural sources, and for that reason during the last few decades, considerable research effort has been focused on obtaining these compounds by synthesis. The most recurrent strategies used for synthesizing these compounds involve, as a first step, the separate preparation of the appropriate terpenyl fragments and the aromatic nucleus. The crucial step is the attachment of the aromatic synthon to the terpenyl skeleton ${ }^{16}$. There are many reports of different methods to accomplish these coupling reactions in the synthesis of prenylphenols, but most of them involve additional activation or protection procedures of precursors obtaining complex mixtures of O-prenyl, C-prenyl and di-C-prenyl phenols with low yields ${ }^{17}$. The electrophilic aromatic substitution $\left(\mathrm{S}_{\mathrm{E}} \mathrm{Ar}\right)$ reaction between a phenol and the desired prenol catalyzed by $\mathrm{BF}_{3} \cdot \mathrm{OEt}_{2}$ is a method of interest because of its simplicity and mild reaction condition $\mathrm{s}^{18,19}$. However, direct prenylation of phenols with electron withdrawing carbonyl groups is difficult because of the reduced activation of the aromatic ring for $\mathrm{S}_{\mathrm{E}} \mathrm{Ar}$ requiring long reaction times and toxic solvents ${ }^{20,21}$.

C-terpenyl acetophenones have been synthesized in modest yields using the terpenyl bromide and a strong alkaline medium as a catalyst in DMF at $80{ }^{\circ} \mathrm{C}^{22}$. These conditions require very dry solvents, and the terpenyl bromide must be generated in a previous step. Also, C-prenylated acetophenones can be produced in two steps using the terpenyl bromide in an alkaline medium and heating at $220{ }^{\circ} \mathrm{C}$ to elicit a Claisen rearrangement that produces $\mathrm{C}$-alkylation. In this reaction, the use of high temperatures, hazardous solvents 
and successive clean-up steps are required to obtain products in moderate yields $^{23}$. C-Prenylated polyhydroxylated acetophenones and flavonoids have synthetized by prenylation of phenols with 2-methyl-3-buten-2-ol in the presence of $\mathrm{BF}_{3} \cdot \mathrm{Et}_{2} \mathrm{O}$ or $\mathrm{ZnCl}_{2}$ as Lewis acid catalysts in dioxane producing alkylated substances in middling yields ${ }^{24,25,26}$.

As natural and synthetic phenolic compounds often show good antioxidant, antibacterial and antifungal activities ${ }^{27,28,29}$,

in this manuscript we describe a simple and easily applicable synthesis of a series of prenylated acetophenone and benzaldehyde derivatives by a direct prenylation using prenol, $\mathrm{ZnCl}_{2}$ as the Lewis acid catalyst and ethyl acetate as the solvent under reflux conditions, as well as their anti-phytophatogenic and antioxidant (DPPH radical scavenging) activities.

\section{EXPERIMENTAL}

\subsection{Synthesis}

\subsubsection{General Data}

All purchased chemical reagents (Merck or Aldrich) were of the highest commercially available purity and were used without previous purification. Melting points $\left(\mathrm{mp}:{ }^{\circ} \mathrm{C}\right)$ were measured on a Stuart-Scientific SMP3 melting point apparatus and are uncorrected. IR spectra were recorded as a thin film (compound 13) or in $\mathrm{KBr}$ disks in a Thermo Scientific Nicolet 6700 FT-IR spectrometer, and wavenumbers are reported in $\mathrm{cm}^{-1}$. Low resolution mass spectra were recorded on a Thermo Scientific, Trace GC Ultra, ISQ mass spectrometer at $70 \mathrm{eV}$ ionizing voltage and are given as $m / z\left(\%\right.$ rel. int.). ${ }^{1} \mathrm{H}-$, ${ }^{13} \mathrm{C}$-(DEPT 135), 2D HSQC and 2D HMBC spectra were recorded in $\mathrm{CDCl}_{3}$ or DMSO- $d$ solutions and referenced to the residual solvent peaks at $\delta 7.26 \mathrm{ppm}$ and $\delta 2.50 \mathrm{ppm}$ for ${ }^{1} \mathrm{H}$ and $\delta 77.0 \mathrm{ppm}$ and $\delta 39.5 \mathrm{ppm}$ for ${ }^{13} \mathrm{C}$, respectively, on a Bruker Avance $400 \mathrm{NMR}$ spectrometer operating at $400.1 \mathrm{MHz}$ for ${ }^{1} \mathrm{H}$ and $100.6 \mathrm{MHz}$ for ${ }^{13} \mathrm{C}$. Chemical shifts are reported as $\delta(\mathrm{ppm})$, and coupling constants $(J)$ are given in Hz. Silica gel (Merck 200-400 mesh) was used for column chromatography and HF-254 silica gel plates for TLC. TLC spots were detected both under a UV lamp and by heating after drenching in $10 \% \mathrm{H}_{2} \mathrm{SO}_{4}$ in $\mathrm{H}_{2} \mathrm{O}$. Antioxidant effects were determined in a Thermo Scientific Multiskan GO 96-well plate photometer.

\subsubsection{General Experimental Procedure}

The appropriate acetophenone or benzaldehyde (1 mol equiv.) and anhydrous $\mathrm{ZnCl}_{2}$ ( 2 mol equiv.) were placed in a round-bottom flask and dissolved in ethyl acetate $(100 \mathrm{~mL})$. Under vigorous stirring, a solution of 3-methyl-2-buten-1-ol (10, 2 mol equiv.) in ethyl acetate $(10 \mathrm{~mL})$ was added dropwise during $1 \mathrm{~h}$ at $40{ }^{\circ} \mathrm{C}$. The reaction mixture was then heated to reflux temperature while the stirring continued. After $2-4 \mathrm{~h}$, a pH 1 aqueous $\mathrm{HCl}$ solution was added to the reaction mixture to decompose the $\mathrm{Zn}$ complex. Then, the organic layer was separated, and a new extraction with ethyl acetate was performed. The pooled organic solutions were dried over anhydrous sodium sulphate and filtered; the solvent was evaporated under reduced pressure. The mixture was subjected to silica gel flash column chromatography (ethyl acetate/hexanes as the mobile phase) to yield the products.

2.1.3. Physical Data of Prenylated Acetophenones and Benzaldehydes 1-(2',4'-Dihydroxy-5'-(3''-methyl-2'"-buten-1 '-yl)phenyl)ethanone (1) was obtained from 1-(2',4'-dihydroxyphenyl)ethanone $(4,2.0 \mathrm{~g}, 13.1 \mathrm{mmol})$, prenol $(\mathbf{1 0}, 2.26 \mathrm{~g}, 26.2 \mathrm{mmol})$, and anhydrous $\mathrm{ZnCl}_{2}(3.57 \mathrm{~g}, 26.2 \mathrm{mmol})$, refluxing for $4 \mathrm{~h}$ as described above. The crude mixture was purified by column chromatography using hexane-ethyl acetate $(70: 30)$ to afford the title compound as a white solid $(1.10 \mathrm{~g}, 38 \%)$; mp: $138-140{ }^{\circ} \mathrm{C}$ (lit..$\left.^{1} 144^{\circ} \mathrm{C}\right)$; MS $\mathrm{m} / \mathrm{z}$ : 220 (100\%), 205 (59\%), 177 (16\%), 165 (99\%), 149 (21\%), 137 (12\%), $69(18 \%)$ (lit. ${ }^{1}$ Anal. Calcd. for $\mathrm{C}_{13} \mathrm{H}$ O: C, 70.89; H, 7.32. Found C, 70.76; $\mathrm{H}, 7.47$; ESI-MS: $m / z[\mathrm{M}+\mathrm{H}+]$ calcd for $\mathrm{C}_{13} \mathrm{H}_{16} \mathrm{O}_{3}: 220.11$; found: 221.24 ); IR $\left(\mathrm{KBr}, \mathrm{cm}^{-1}\right): 3282,2967,2912,2849,1638,1618,1509,1420,1378 ;{ }^{1} \mathrm{H}-\mathrm{NMR}$ $\left(\mathrm{CDCl}_{3}\right): 12.53$ (s, $1 \mathrm{H}, \mathrm{ArC}-2$ '-OH); 7.43 (s, $\left.1 \mathrm{H}, \mathrm{ArH}-\mathrm{6}^{\prime}\right) ; 6.36$ (s, $1 \mathrm{H}, \mathrm{ArH}-$ $\left.3^{\prime}\right) ; 6.11\left(\mathrm{~s}, 1 \mathrm{H}, \mathrm{ArC}-4^{\prime}-\mathrm{OH}\right) ; 5.28\left(\mathrm{~m}, 1 \mathrm{H}, \mathrm{C}=\mathrm{CHCH}_{2}\right) ; 3.30(\mathrm{~d}, 2 \mathrm{H}, J=7.2$ $\left.\mathrm{Hz}, \mathrm{C}=\mathrm{CHCH}_{2}\right) ; 2.55\left(\mathrm{~s}, 3 \mathrm{H}, \mathrm{O}=\mathrm{CCH}_{3}\right) ; 1.78\left[\mathrm{~s}, 6 \mathrm{H}, \mathrm{CHC}\left(\mathrm{CH}_{3}\right)_{2}\right] ;{ }^{13} \mathrm{C}-\mathrm{NMR}$ $\left(\mathrm{CDCl}_{3}\right): 17.9^{2}\left(\mathrm{CH}_{3} \mathrm{CH}_{3} \mathrm{C}=\mathrm{CH}_{2}-\right) ; 25.8\left(\mathrm{CH}_{3} \mathrm{CH}_{3} \mathrm{C}=\mathrm{CH}_{2}\right) ; 26.2\left(\mathrm{O}=\mathrm{CCH}_{3}\right)$; $28.9\left(\mathrm{C}^{2} \mathrm{CHCH}_{2}-\right) ; 103.7\left(\mathrm{ArCH}-3^{\prime}\right) ; 114.0\left(\mathrm{ArC}-1^{\prime}\right) ; 118.9\left(\mathrm{ArC}-5^{\prime}\right) ; 121.4$ $\left(\mathrm{C}=\mathrm{CHCH}_{2}\right) ; 132.2(\mathrm{ArCH}-6$ ' $) ; 135.3\left(\mathrm{C}^{2}=\mathrm{CHCH}_{2}\right) ; 161.6\left(\mathrm{ArC}-4^{\prime}\right) ; 163.5$ ( $\left.\mathrm{ArC}-2^{\prime}\right) ; 202.7\left(\mathrm{CH}_{3} \mathrm{C}=\mathrm{O}\right)$.

1-(2',6'-Dihydroxy-3'-(3'--methyl-2'"-buten-1 '-yl)phenyl)ethanone (11) was obtained from 1-(2',6'-dihydroxyphenyl)ethanone (5, $2.0 \mathrm{~g}, 13.1 \mathrm{mmol})$, prenol (10, $2.26 \mathrm{~g}, 26.2 \mathrm{mmol})$, and anhydrous $\mathrm{ZnCl}_{2}(3.57 \mathrm{~g}, 26.2 \mathrm{mmol})$, refluxing for $2 \mathrm{~h}$ as described above. The crude mixture was purified by column chromatography using hexane-ethyl acetate (80:20) to afford the title compound as a pale green solid $(1.15 \mathrm{~g}, 40 \%) ; \mathrm{mp}: 80-82{ }^{\circ} \mathrm{C}\left(\right.$ lit. $\left.^{21} 80-81^{\circ} \mathrm{C}\right) ; \mathrm{MS} m / z$ : 220 (67\%), 205 (23\%), 187 (12\%), 177 (15), 165 (100\%), 149 (28\%), 121 (12\%), 91 (11\%) (lit. ${ }^{21}$ EI-HRMS Calcd for $\mathrm{C}_{11} \mathrm{H}_{1} \mathrm{O}_{3}(\mathrm{M}+)$ 220.1099, Found 220.1102); IR ( $\left.\mathrm{KBr}, \mathrm{cm}^{-1}\right): 3346,2964,2925,1597,1569,1421,1374 ;{ }^{1} \mathrm{H}-\mathrm{NMR}$ $\left(\mathrm{CDCl}_{3}\right)$ : 10.08 (s, 1H, ArC-6'-OH); 9.27 (s, 1H, ArC-2'-OH); 7.12 (d, 1H, J $=8.3 \mathrm{~Hz}, \operatorname{Ar} H-4^{\prime}$ ); 6.33 (d, $\left.1 \mathrm{H}, J=8.3 \mathrm{~Hz}, \mathrm{Ar} H-5^{\prime}\right) ; 5.28$ (br. t, $1 \mathrm{H}, J=7.2$ $\left.\left.\mathrm{Hz}, \mathrm{C}=\mathrm{CHCH}_{2}\right) ; 3.28(\mathrm{~d}, 2 \mathrm{H}, J=7.2 \mathrm{~Hz}, \mathrm{C}=\mathrm{CHCH})_{2}\right) 2.73\left(\mathrm{~s}, 3 \mathrm{H}, \mathrm{O}=\mathrm{CCH}_{3}\right) ;$ $1.77\left(\mathrm{~s}, 6 \mathrm{H}, \mathrm{CH}=\mathrm{C}\left(\mathrm{CH}_{3}\right)_{2}\right] ;{ }^{13} \mathrm{C}-\mathrm{NMR}\left(\mathrm{CDCl}_{3}\right): 17.8\left(\mathrm{CH}_{3} \mathrm{CH}_{3} \mathrm{C}=\mathrm{CH}_{2}-\right) ; 25.8$ $\left(\mathrm{CH}_{3} \mathrm{CH}_{3} \mathrm{C}=\mathrm{CH}_{2}-\right) ; 28.7\left(\mathrm{C}=\mathrm{CHCH}_{2}-\right) ; 33.6\left(\mathrm{O}=\mathrm{CCH}_{3}\right) ; 107.3(\mathrm{ArCH}-5)$; 110.2 ( $\left.\mathrm{ArC}-1^{\prime}\right) ; 119.3\left(\mathrm{ArC}-3^{\prime}\right) ; 121.6\left(\mathrm{C}=\mathrm{CHCH}_{2}\right) ; 134.9\left(\mathrm{C}^{\prime}=\mathrm{CHCH}_{2}\right) ; 136.2$ (ArCH-4'); $159.3\left(\operatorname{ArC}-2^{\prime}\right) ; 159.7\left(\operatorname{ArC}-6^{\prime}\right) ; 205.5\left(\mathrm{CH}_{3} \mathrm{C}=\mathrm{O}\right)$.

1-(2',4',6'-Trihydroxy-3'-(3''-methyl-2',-buten-1 ',-yl)phenyl)ethanone (12) was obtained from 1-(2',4',6'-trihydroxyphenyl) ethanone (6, $2.0 \mathrm{~g}, 10.7$ $\mathrm{mmol})$, prenol (10, $1.84 \mathrm{~g}, 21.4 \mathrm{mmol})$, and anhydrous $\mathrm{ZnCl}_{2}(2.92 \mathrm{~g}, 21.4$ $\mathrm{mmol}$ ), refluxing for $4 \mathrm{~h}$ as described above. The crude mixture was purified by column chromatography using hexane-ethyl acetate (50:50) to afford the title compound as a pale yellow solid $(1.13 \mathrm{~g}, 45 \%)$; mp: $174{ }^{\circ} \mathrm{C}$ (lit. $.^{32} 173-$ $174^{\circ} \mathrm{C}$ ); MS m/z: 236 (68\%), 193 (33\%), 181 (100\%), 165 (47\%) (lit..$^{32}$ M.W. Found 238 Calcd. 236); IR (KBr, $\left.\mathrm{cm}^{-1}\right): 3420,3333,2973,2922,2864,1635$, $1599,1560,1450,1434$; 1H-NMR (DMSO- $\left.d_{6}\right): 14.00$ (s, 1H, ArC-2'-OH); 10.51 (s, $\left.1 \mathrm{H}, \mathrm{ArC}-4^{\prime}-\mathrm{OH}\right) ; 10.28$ (s, $\left.1 \mathrm{H}, \mathrm{ArC}-6^{\prime}-\mathrm{O} H\right)$; 5.98 (s, $\left.1 \mathrm{H}, \mathrm{Ar} H-5^{\prime}\right)$; $5.09\left(\mathrm{~m}, 1 \mathrm{H}, \mathrm{C}=\mathrm{CHCH}_{2}\right) ; 3.05\left(\mathrm{~d}, 2 \mathrm{H}, J=7.1 \mathrm{~Hz}, \mathrm{C}=\mathrm{CHCH}_{2}\right) ; 2.53(\mathrm{~s}, 3 \mathrm{H}$, $\left.\mathrm{O}=\mathrm{CCH}_{3}\right) ; 1.66\left(\mathrm{~s}, 3 \mathrm{H}, \mathrm{CHCCH}_{3} \mathrm{CH}_{3}\right) ; 1.58\left(\mathrm{~s}, 3 \mathrm{H}, \mathrm{CHCCH}_{3} \mathrm{CH}_{3}\right) ;{ }^{13} \mathrm{C}-\mathrm{NMR}$ $\left(\mathrm{CDCl}_{3}\right): 17.6\left(\mathrm{CH}_{3} \mathrm{CH}_{3} \mathrm{C}=\mathrm{CH}_{2}-\right) ; 20.9\left(\mathrm{C}=\mathrm{CHCH}_{2}\right) ; 25.5\left(\mathrm{CH}_{3} \mathrm{CH}_{3} \mathrm{C}=\mathrm{CH}_{2}-\right)$; $32.4\left(\mathrm{O}=\mathrm{CCH}_{3}\right) ; 94 .{ }^{3}\left(\mathrm{ArCH}-5^{\prime}\right) ; 103.8\left(\mathrm{ArC}^{2}{ }^{\prime}\right) ; 105.7\left(\mathrm{ArC}-3^{\prime}\right) ; 123.3$ $\left(\mathrm{C}=\mathrm{CHCH}_{2}\right) ; 129.5\left(\mathrm{C}^{2} \mathrm{CHCH}_{2}\right) ; 160.2\left(\mathrm{ArC}-6^{\prime}\right) ; 162.4\left(\mathrm{ArC}-4^{\prime}\right) ; 163.2(\mathrm{ArC}-$ $\left.2^{\prime}\right) ; 202.5\left(\mathrm{CH}_{3} \mathrm{C}=\mathrm{O}\right)$.

1-(2'-Hydroxy-4',6'-dimethoxy-3'-(3' '-methyl-2' '-buten-1 ''-yl)phenyl) ethanone (13) was obtained from 1-(2'-hydroxy-4',6'-dimethoxyphenyl) ethanone (7, $1.0 \mathrm{~g}, 5.1 \mathrm{mmol})$, prenol $(\mathbf{1 0}, 0.88 \mathrm{~g}, 10.2 \mathrm{mmol})$, and anhydrous $\mathrm{ZnCl}_{2}(1.39 \mathrm{~g}, 10.2 \mathrm{mmol})$, refluxing for $4 \mathrm{~h}$ as described above. The crude mixture was purified by column chromatography using using hexane-ethyl acetate $(90: 10)$ to afford the title compound as a pale yellowish oil $(0.64 \mathrm{~g}$, 48\%); MS m/z: 264 (86\%), 249 (100\%), 233 (8\%), 207 (14\%), $181(24 \%) 69$ (8) (lit. ${ }^{33}$ Anal. Found: C, 68.58\%; H, 7.85\%; Calcd for $\mathrm{C}_{15} \mathrm{H}_{20} \mathrm{O}_{5}$ : C, $68.18 \%$; H, 7.57\%); IR (Film, $\mathrm{cm}^{-1}$ ): 2966, 2936, 2856, 1698, 1619, $1589,1580,1443$, 1406, 1363; ${ }^{1} \mathrm{H}-\mathrm{NMR}\left(\mathrm{CDCl}_{3}\right): 13.38$ (s, $\left.1 \mathrm{H}, \mathrm{ArC}-2{ }^{\prime}-\mathrm{OH}\right) ; 6.25$ (s, $1 \mathrm{H}, \mathrm{ArH}-$ 5'); 5.13 (br. t, $\left.1 \mathrm{H}, \mathrm{CCHCH}_{2}\right) ; 3.84\left(\mathrm{~s}, 3 \mathrm{H}, \mathrm{OCH}_{3}\right) ; 3.72\left(\mathrm{~s}, 3 \mathrm{H}, \mathrm{OCH}_{3}\right) ; 3.25(\mathrm{~d}$, $\left.2 \mathrm{H}, J=6.6 \mathrm{~Hz}, \mathrm{C}=\mathrm{CHCH}_{2}\right) ; 2.68\left(\mathrm{~s}, 3 \mathrm{H}, \mathrm{O}=\mathrm{CCH}_{3}\right) ; 1.76\left(\mathrm{~s}, 3 \mathrm{H}, \mathrm{CHCCH}_{3} \mathrm{CH}_{3}\right)$; $1.68\left(\mathrm{~s}, 3 \mathrm{H}, \mathrm{CHCCH}_{3} \mathrm{CH}_{3}\right) ;{ }^{13} \mathrm{C}-\mathrm{NMR}\left(\mathrm{CDCl}_{3}\right): 17.8\left(\mathrm{CH}_{3} \mathrm{CH}_{3} \mathrm{C}=\mathrm{CH}_{2}-\right) ; 22.4$ $\left(\mathrm{C}=\mathrm{CHCH}_{2}\right) ; 25.7\left(\mathrm{CH}_{3} \mathrm{CH}_{3} \mathrm{C}=\mathrm{CH}_{2}\right) ; 30.8\left(\mathrm{O}=\mathrm{CCH}_{3}\right) ; 55.8\left(\mathrm{OCH}_{3}\right) ; 62.7$ $\left(\mathrm{OCH}_{3}\right) ; 96.0\left(\mathrm{ArCH}-5^{\prime}\right) ; 109.0\left(\mathrm{ArC}-1^{\prime}\right) ; 115.6\left(\mathrm{ArC}-3^{\prime}\right) ; 123.0\left(\mathrm{C}=\mathrm{CHCH}_{2}\right)$; $131.5\left(C^{\prime}=\mathrm{CHCH}_{2}\right) ; 161.6\left(\mathrm{ArC}-2^{\prime}\right) ; 164.6\left(\mathrm{ArC}-4^{\prime}, 6^{\prime}\right) ; 203.3\left(\mathrm{CH}_{3} \mathrm{C}=\mathrm{O}\right)$.

2,4-Dihydroxy-5-(3'-methyl-2'-buten-1'-yl)benzaldehyde (14) was obtained from 2,4-dihydroxybenzaldehyde $(\mathbf{8}, 2.0 \mathrm{~g}, 14.5 \mathrm{mmol})$, prenol (10, $2.50 \mathrm{~g}, 29.0 \mathrm{mmol})$, and anhydrous $\mathrm{ZnCl}_{2}(3.95 \mathrm{~g}, 29.0 \mathrm{mmol})$, refluxing for $2 \mathrm{~h}$ as described above. The crude mixture was purified by column chromatography using hexane-ethyl acetate (70:30) to afford the title compound. The solid was recrystallized from dichloromethane/hexane mixture to give a white solid (0.68 g, $23 \%$ ); mp: $140-142{ }^{\circ} \mathrm{C}$ (lit. $.^{20} 121-123^{\circ} \mathrm{C}$, lit. $.^{49} 140.5-141.0^{\circ} \mathrm{C}$ ); MS $\mathrm{m} / z$ : 206 (81\%), 191 (28\%), 163 (40\%), 151 (100\%), 69 (21\%) (lit. ${ }^{20}$ LCEIMS: m/z: 205 [M-H]-); IR (KBr, cm-1): 3313, 3054, 2967, 2912, 2833, 1643 , 1600, 1505, 1443, 1426; ${ }^{1} \mathrm{H}-\mathrm{NMR}\left(\mathrm{CDCl}_{3}\right): 11.26(\mathrm{~s}, 1 \mathrm{H}, \mathrm{ArC}-2-\mathrm{OH}) ; 9.68$ (s, 1H, CHO); 7.24 (s, 1H, ArH-6); 6.37 (s, 1H, ArH-3); 6.24 (s, 1H, ArC-4$\mathrm{OH}) ; 5.29$ (br. t, $\left.1 \mathrm{H}, \mathrm{C}=\mathrm{CHCH}_{2}\right) ; 3.31\left(\mathrm{~d}, 2 \mathrm{H}, J=7.2 \mathrm{~Hz}, \mathrm{C}=\mathrm{CHCH}_{2}\right) ; 1.79$ (s, $\left.3 \mathrm{H}, \mathrm{CHCCH}_{3} \mathrm{CH}_{3}\right) ; 1.76\left(\mathrm{~s}, 3 \mathrm{H}, \mathrm{CHCCH}_{3} \mathrm{CH}_{3}\right) ;{ }^{13} \mathrm{C}-\mathrm{NMR}\left(\mathrm{CDCl}_{3}\right): 17.9$ $\left(\mathrm{CH}_{3} \mathrm{CH}_{3} \mathrm{C}=\mathrm{CH}_{2}-\right) ; 25.8\left(\mathrm{CH}_{3} \mathrm{CH}_{3} \mathrm{C}=\mathrm{CH}_{2}-\right) ; 28.4\left(\mathrm{C}=\mathrm{CHCH}_{2}-\right) ; 103.3(\mathrm{ArCH}-$ 3); $115.2(\mathrm{ArC}-1) ; 120.0(\mathrm{ArC}-5) ; 121.0\left(\mathrm{C}=\mathrm{CHCH}_{2}\right) ; 135.1$ ( $\left.\mathrm{ArCH}-6\right) ; 135.7$ $\left(C=\mathrm{CHCH}_{2}\right) ; 162.4(\mathrm{ArC}-4) ; 162.8(\mathrm{ArC}-2) ; 194.5(\mathrm{HC}=\mathrm{O})$.

3,4-Dihydroxy-5-(3'-methyl-2'-buten-1 '-yl)benzaldehyde (15) was obtained from 3,4-dihydroxybenzaldehyde $(\mathbf{9}, 2.0 \mathrm{~g}, 14.5 \mathrm{mmol})$, prenol (10, $2.50 \mathrm{~g}, 29.0 \mathrm{mmol})$, and anhydrous $\mathrm{ZnCl}_{2}(3.95 \mathrm{~g}, 29.0 \mathrm{mmol})$, refluxing for $2 \mathrm{~h}$ as described above. The crude mixture was purified by column chromatography using hexane-ethyl acetate $(60: 40)$ to afford the title compound. The solid was recrystallized from dichloromethane/hexane mixture to give a white solid $(0.60$ g, 21\%); mp: $145-147^{\circ} \mathrm{C}$ (lit. ${ }^{34} 72-73^{\circ} \mathrm{C}$ ); MS m/z: 206 (97\%), 151 (100\%), 77 (11\%) (lit. $\left.{ }^{34} \mathrm{~m} / \mathrm{z}: 206[\mathrm{M}+]\right)$; IR (KBr, $\left.\mathrm{cm}^{-1}\right): 3350,2962,2914,2855,1644$, $1613,1594,1522,1445$; ${ }^{1} \mathrm{H}-\mathrm{NMR}$ (DMSO-d ): $9.66(\mathrm{~s}, 1 \mathrm{H}, \mathrm{CHO}) ; 7.13(\mathrm{~d}$, $2 \mathrm{H}, J=1.9 \mathrm{~Hz}, \mathrm{Ar} H-2,6$ ); 5.27 (br. t, $1 \mathrm{H}, \mathrm{C}=\mathrm{CHCH}_{2}$ ); 3.34 (br. s, $2 \mathrm{H}, \mathrm{ArC}-$ $3,4-\mathrm{OH}) ; 3.25\left(\mathrm{~d}, 2 \mathrm{H}, J=7.3 \mathrm{~Hz}, \mathrm{C}=\mathrm{CHCH}_{2}\right) ; 1.68\left(\mathrm{~s}, 3 \mathrm{H}, \mathrm{CHCCH}_{3} \mathrm{CH}_{3}\right) ; 1.66$ (s, 3H, $\left.\mathrm{CHCCH}_{3} \mathrm{CH}_{3}\right) ;{ }^{13} \mathrm{C}-\mathrm{NMR}$ (DMSO-d $): 17.6\left(\mathrm{CH}_{3} \mathrm{CH}_{3} \mathrm{C}=\mathrm{CH}_{2}-\right) ; 25.5$ $\left(\mathrm{CH}_{3} \mathrm{CH}_{3} \mathrm{C}=\mathrm{CH}_{2}-\right) ; 27.8\left(\mathrm{C}=\mathrm{CHCH}_{2}-\right) ; 112.0(\mathrm{ArCH}-2) ; 122.1\left(\mathrm{C}=\mathrm{CHCH}_{2}\right)$; 
$124.2(\mathrm{ArCH}-6) ; 127.9(\mathrm{ArC}-1) ; 128.3(\mathrm{ArC}-5) ; 131.9\left(\mathrm{C}=\mathrm{CHCH}_{2}\right) ; 145.2$ (ArC-3); $149.7(\mathrm{ArC}-4) ; 191.2(\mathrm{HC}=\mathrm{O})$.

\subsection{Cytotoxicity Assays}

\subsubsection{In Vitro Antibacterial Activity Assays}

Liquid-dilution methods were used to evaluate the effects of the compounds on the growth of Erwinia carotovora (NCPPB 312), Agrobacterium tumefaciens (strain C58C1) and Pseudomonas syringae (NCPPB 281). Bacteria were grown in sterile tubes with $10 \mathrm{~mL}$ of Müller-Hinton $(\mathrm{MH})$ medium and incubated at $27{ }^{\circ} \mathrm{C}$ for $12 \mathrm{~h}$ with shaking to produce an initial culture. The antimicrobial activity was evaluated by observing the growth response of both micro-organisms in samples with different concentrations of the compounds $\mathrm{s}^{36-38}$. All assays were performed on sterile 96-well microplates with a final volume of $200 \mu \mathrm{L}$ containing Müller-Hinton broth (MH) inoculated with $1 \mu \mathrm{L}$ aliquots of bacterial suspension (105-106 UFC/mL, initial culture) in the presence of different concentrations of test compounds $(3.9,7.8,15.6$, $31.3,62.5,125$ and $250 \mu \mathrm{M})$. MH was used as the negative control $[\mathrm{C}(-)]$, and $\mathrm{MH}$ with streptomycin ${ }^{39}$ was used as the positive control $[\mathrm{C}(+)]$. The plates were incubated for $7 \mathrm{~h}$ at $27^{\circ} \mathrm{C}$. Bacterial growth was monitored by measuring the optical density at $595 \mathrm{~nm}$ every hour with a microplate reader. All tests were performed in ten repetitions for each microorganism evaluated. Bacterial growth was shown as the arithmetic mean expressed in terms of the negative control (100\% growth). The lowest concentration of the compound preventing the appearance of turbidity was considered to be the minimal inhibitory concentration (MIC).

The first experiment (first kinetic assay) in which the compound was exposed to the bacterial cultures in MH was carried out over a period of 6 hours. Subsequently, to determine the minimal bactericidal concentration (MBC), a second experiment (second kinetic assay) was conducted; this experiment involved taking inoculum from the first kinetic assay and adding it to $\mathrm{MH}$ in a new 96-well microplate, which was then cultured for 7 hours. The aim of this second culture (second kinetic assay) was to observe and quantify the ability of bacterial cultures to recover from the cytotoxic effect caused by the compounds, which is evidenced by the presence or absence of bacterial growth. This second experiment allows a more accurate conclusion to be reached: if the bacterial culture's growth declines with respect to the culture of the first kinetic assay, then it is related to a bactericidal property. If, on the other hand, the growth continues in line with that of the culture of first kinetic assay, then it is related to a bacteriostatic property.

\subsubsection{In Vitro Fungicidal Activity Assays}

A virulent isolate of Botrytis cinerea obtained from naturally infected grape berries ${ }^{40}$ was prepared and maintained by plating it on potato dextrose agar at $5{ }^{\circ} \mathrm{C}$. Phytophthora cinnamomi was kindly provided by the National Institute of Agricultural Research (INIA, La Platina, Santiago, Chile). The fungus Gibberella fujikuroi was kindly provided by Dr. B. Fraga, Natural Products and Agrobiology Institute, CSIC, Canary Islands, Spain. The agar dilution technique was used to evaluate the effect of the prenylated compounds on the growth of $P$. cinnamomi $i^{41,42}, G$. fujikuroi $i^{43}$ and $B$. cinere ${ }^{4,45}$. Fungicidal activity assays of these compounds were performed in microcultures by growing the fungi in sterile Petri dishes $(35 \mathrm{~mm})$ at a final volume of $2 \mathrm{~mL}$ medium containing different compound concentrations. Clarified V8 (Campbell Soup) medium containing metalaxyl ${ }^{46}$ for $P$. cinnamomi or PDA medium for $B$. cinerea and G. fujikuroi with captan ${ }^{47,48}$ was used as the positive control $[\mathrm{C}(+)]$, and without fungicide as the negative control $[\mathrm{C}(-)])$. The medium in each slot was then inoculated with a small block $(4 \mathrm{~mm})$ of clarified V8 or PDA medium containing fungal hyphae excised from the edge of an actively growing culture. The fungal growth was monitored at different times (24-72 hours). To determine the growth of mycelium in the agar plate, the surface of the mycelium was measured using Sigma Scan Pro 5 software. The final results are expressed as percent growth inhibition, calculated according to the control without fungicide. Each treatment was independently performed in triplicate.

\subsubsection{Statistics}

A one-way ANOVA was performed to identify significant differences among the treatment and control groups. Tukey's honest significant difference test was applied to compare the means of every treatment against the control and simultaneously establish their significance $(\mathrm{P}<0.05)$. All data are presented as mean \pm standard deviation (mean \pm S.D.).

2.3 General Procedure to Determine Antioxidant Activity (DPPH Radical Scavenging Activity)

The radical scavenging activity of the prenylated compounds and starting materials towards the 2,2-diphenyl-1-picrylhydrazyl (DPPH) radical was measured as described ${ }^{35}$, with modifications to adapt the screen to $96-$ well plates. Stock solutions of each compound were prepared in methanol at a 1 $\mathrm{mM}$ concentration $(10 \mathrm{~mL})$. Dilutions $(1-200 \mu \mathrm{M})$ were prepared from the stock solutions. Methanol $(90 \mu \mathrm{L})$, each dilution $(150 \mu \mathrm{L})$, and DPPH $(60$ $\mu \mathrm{L}$, Sigma-Aldrich) in methanol $(0.5 \mathrm{mM})$, resulting in a final concentration of $0.1 \mathrm{mM} \mathrm{DPPH}$, were added in a 96-well plate. Methanol was used as the blank sample. The mixtures were left for $30 \mathrm{~min}$ at room temperature, and the absorbances were then measured at $517 \mathrm{~nm}$. Trolox was used as the standard antioxidant. The radical scavenging activity was calculated as follows: $\%$ Inhibition $=[($ blank absorbance - sample absorbance $) /$ blank absorbance $] \times$ 100. The mean of three $\mathrm{IC}_{50}$ (concentration causing 50\% inhibition) values for each compound was determined graphically.

\section{RESULTS AND DISCUSSION}

\subsection{Chemistry}

The synthesis of prenylated phenols was carried out in one step via the $S_{\mathrm{E}} \mathrm{Ar}$ mechanism as shown in Scheme 1. The reaction of different acetophenones (4, $\mathbf{5}, \mathbf{6}$ and 7) and benzaldehydes $(\mathbf{8}, 9)$ with prenol in the presence of $\mathrm{ZnCl}_{2}$ in ethyl acetate produced prenylated acetophenones 1, 11-13 and prenylated benzaldehydes 14-15 in moderate yields (38-48\% and $21-23 \%$, respectively), leaving abundant unreacted aromatic starting material. Yields improved significantly by considering only reacted starting material (e.g. compound $\mathbf{1}$ from $38 \%$ up to $73 \%$; compound $\mathbf{1 1}$ from $40 \%$ up to $55 \%$; compound 12 from $45 \%$ up to $63 \%$; compound $\mathbf{1 3}$ from $48 \%$ up to $60 \%$; compound $\mathbf{1 4}$ from $23 \%$ up to $50 \%$; compound $\mathbf{1 5}$ from $21 \%$ up to $45 \%$ ).

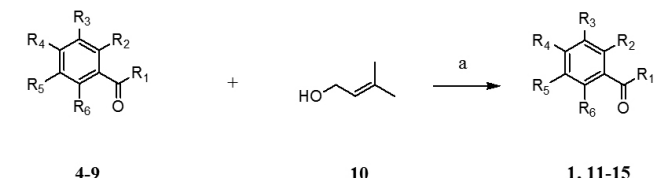

4. $\mathrm{R}_{1}=\mathrm{CH}_{3} ; \mathrm{R}_{2}=\mathrm{R}_{4}=\mathrm{OH} ; \mathrm{R}_{3}=\mathrm{R}_{5}=\mathrm{R}_{6}=\mathrm{H}$ 5. $\mathrm{R}_{1}=\mathrm{CH}_{3} ; \mathrm{R}_{2}=\mathrm{R}_{6}=\mathrm{OH} ; \mathrm{R}_{3}=\mathrm{R}_{4}=\mathrm{R}_{5}=\mathrm{H}$
6. $\mathrm{R}_{1}=\mathrm{CH}_{3} ; \mathrm{R}_{2}=\mathrm{R}_{4}=\mathrm{R}_{6}=\mathrm{OH} ; \mathrm{R}_{3}=\mathrm{R}_{5}=\mathrm{H}$ 6. $\mathrm{R}_{1}=\mathrm{CH}_{3} ; \mathrm{R}_{2}=\mathrm{R}_{4}=\mathrm{R}_{6}=\mathrm{OH} ; \mathrm{R}_{3}=\mathrm{R}_{5}=\mathrm{H}$
7. $\mathrm{R}_{1}=\mathrm{CH}_{3}: \mathrm{R}_{2}=\mathrm{OH} ; \mathrm{R}_{4}=\mathrm{R}_{6}=\mathrm{OCH} 3 \mathrm{R}_{3}=\mathrm{R}_{5}=\mathrm{H}$ 8. $R_{1}=R_{3}=R_{5}=R_{6}=H ; R_{2}=R_{4}=O H$
9. $R_{1}=R_{2}=R_{3}=R_{6}=H ; R_{4}=R_{5}=O H$ 1,11-15

Scheme 1. One-step synthesis of prenylated polyhydroxylated acetophenones and benzaldehydes. Conditions and reagents: (a): $\mathrm{ZnCl}_{2} /$ AcOEt, $40{ }^{\circ} \mathrm{C}$, reflux, 2-4 $\mathrm{h} \rightarrow \mathbf{1}, \mathbf{1 1 - 1 5}$.

It is possible that polyalkylations occurred in very small yields as byproducts in these reactions. Despite the fact that the TLC plates displayed multiple spots, the monoalkylated product and starting material are the main components of these reaction mixtures. The $\mathrm{ZnCl}_{2}$ must be dry because moisture negatively affects the quality of the catalyst and the reaction yield. Poor to reasonable yields of prenylation were obtained under the reaction conditions used (in the presence of air) giving several non-isolated compounds. Reflux conditions forced us to conduct the reactions in a non-inert atmosphere. This could lead to complex reaction mixtures due to oxidations and other side reactions. Benzaldehyde 9 and its prenylated derivative $\mathbf{1 5}$ have two ortho$\mathrm{OH}$ groups bound to the benzene moiety; this catechol function might lead to oxidative processes under these reaction conditions. The yields were markedly improved when calculated only from reacted acetophenone and benzaldehyde because abundant aromatic starting material was recovered from all the reactions after column chromatography. Longer reaction times led to complex mixtures and losses of the main product in all cases. Side reactions led to lower allylation yields. Elimination reaction mechanisms can also occur in the allylic carbocation under these reaction conditions. Vanillin and compounds with only one free hydroxyl group did not react under these conditions because the molecules are probably not sufficiently activated due the presence of the electron-withdrawing carbonyl group. Additional hydroxyl groups on the ring structure of these compounds enhance the reactivity and favor electrophilic attack.

We believe that the regioselectivity achieved with this methodology is of particular intrerest; it arises during the key step of $\mathrm{Zn}$ (II) complexation to both the phenol and allylic alcohol substrates. After coordination, the allylic residue is located adjacent to the phenol function. Thereupon, the active ortho carbon of the phenol ring is joined to the allylic carbocation intermediate of the prenol. A similar alkylation mechanism was proposed for the $\mathrm{C}$-acylation of phenol and naphtol derivatives catalyzed by $\mathrm{ZnCl}_{2}$ supported on $\mathrm{Al}_{2} \mathrm{O}_{3}$ as a catalyst 
under solvent-free and microwave conditions [30,31]. Also, the allylation position was primarily in the less sterically hindered position in all the isolated products.

The structure of 1 was mainly established by NMR, where aromatic ring proton signals at $\delta_{\mathrm{H}}=7.45(\mathrm{~s}, 1 \mathrm{H})$ and $\delta_{\mathrm{H}}=6.35(\mathrm{~s}, 1 \mathrm{H})$ were observed as two singlets for $\mathrm{H}-6$ and $\mathrm{H}-3$, confirming the aromatic mono-substitution position. Also, the doublet at $\delta_{\mathrm{H}}=3.30 \mathrm{ppm}$ assigned to the methylene group bound to aromatic ring carbon $\mathrm{C}-5\left(\mathrm{~d}, 2 \mathrm{H}, J=7.2 \mathrm{~Hz}, \mathrm{C}=\mathrm{CHCH}_{2}\right)$ confirmed the occurrence of C-alkylation but not O-alkylation. On the other hand, the point of coupling between the prenyl fragment and the aromatic ring of compound $\mathbf{1 1}$ was confirmed by the presence of the signal at $3.28 \mathrm{ppm}(\mathrm{d}, J=7.2 \mathrm{~Hz}, 2 \mathrm{H})$ assigned to the $\mathrm{CH}_{2}-1$ " hydrogens, which was correlated (by 2D HSQC) with the carbon atom at $\delta 28.7 \mathrm{ppm}\left(\mathrm{CH}_{2}-1^{\prime \prime}\right)$ and corroborated by the $2 \mathrm{D} \mathrm{HMBC}{ }^{3} J$ heteronuclear correlations between $\mathrm{CH}_{2}-1$ " and the carbon signals at $\delta 136.2$
(ArCH-4'), 159.3 (ArC-2') ppm and ${ }^{2} J$ heteronuclear correlations with $\delta 121.6$ (CH-2') ppm (Figure S7). Similarly, we could determine the structure of all the synthesized compounds and confirm prenylation ortho with respect to the same hydroxyl group. All these compounds were previously known, and their experimental data (NMR, GC-MS, IR, m.p.) were obtained to confirm their structures and compared with data from the literature for $\mathbf{1}^{1}, \mathbf{1 1}^{21}, \mathbf{1 2}^{32}, \mathbf{1 3}^{33}$, $14^{20}$ and $15^{34}$

\subsection{Anti-Phytopathogenic Activity}

The inhibitory effect was evaluated as the percentage of growth inhibition, calculated using the area of mycelial growth of each fungus in the presence and absence of prenylated compounds. The means of three independent assays are summarized in Table 1. For comparison, the values of the percentage of growth inhibition obtained with the commercial antifungals captan and metalaxyl, widely used to control the growth of $B$. cinerea and $P$. cinnamomi, are included.

Table 1. Inhibition of mycelial growth (\%) of plant pathogenic fungi in the presence of prenylated compounds.

\begin{tabular}{|c|c|c|c|c|c|c|c|c|c|}
\hline \multirow{3}{*}{$\mathbf{N}^{\circ}$ Comp. } & \multicolumn{9}{|c|}{ Percentage of inhibition of mycelial growth of fungal plant pathogens } \\
\hline & \multicolumn{3}{|c|}{ B. cinerea } & \multicolumn{3}{|c|}{ P. cinnamomi } & \multicolumn{3}{|c|}{ G. fujikuroi } \\
\hline & $250 \mu \mathrm{M}$ & $500 \mu \mathrm{M}$ & $1000 \mu \mathrm{M}$ & $250 \mu \mathrm{M}$ & $500 \mu \mathrm{M}$ & $1000 \mu \mathrm{M}$ & $250 \mu \mathrm{M}$ & $500 \mu \mathrm{M}$ & $1000 \mu \mathrm{M}$ \\
\hline 1 & 0 & 0 & $83.71 \pm 0.59$ & 0 & $38.49 \pm 0.26$ & $58.68 \pm 0.72$ & $44.33 \pm 0.53$ & $56.60 \pm 0.74$ & $64.08 \pm 1.69$ \\
\hline 11 & 0 & 0 & 0 & 0 & $32.42 \pm 0.57$ & $38.84 \pm 0.41$ & $59.58 \pm 0.90$ & $63.51 \pm 0.52$ & $65.34 \pm 0.72$ \\
\hline 12 & $61.27 \pm 0.65$ & $70.18 \pm 0.35$ & $83.71 \pm 0.63$ & 0 & $31.69 \pm 0.53$ & $80.51 \pm 0.72$ & $54.75 \pm 0.77$ & $66.13 \pm 0.72$ & $74.59 \pm 0.88$ \\
\hline 13 & 0 & 0 & $83.71 \pm 0.63$ & 0 & $54.72 \pm 0.51$ & $80.51 \pm 0.72$ & $26.40 \pm 0.55$ & $40.94 \pm 0.52$ & $40.95 \pm 0.51$ \\
\hline 14 & 0 & 0 & 0 & $52.70 \pm 0.52$ & $57.21 \pm 0.72$ & $65.28 \pm 0.77$ & $64.99 \pm 0.71$ & $70.52 \pm 0.57$ & $73.28 \pm 0.54$ \\
\hline \multirow[t]{3}{*}{15} & 0 & 0 & $100 \pm 0.01$ & $100 \pm 0.00$ & $100 \pm 0.00$ & $100 \pm 0.01$ & $53.46 \pm 1.09$ & $78.06 \pm 0.28$ & $100 \pm 0.01$ \\
\hline & $\mathrm{C}+* a$ & \multicolumn{2}{|l|}{$83.69 \pm 0.42$} & \multicolumn{3}{|c|}{$66.10 \pm 0.43$} & \multicolumn{3}{|c|}{$\mathrm{C}+* a \quad 90.97 \pm 0.52$} \\
\hline & C-* & \multicolumn{2}{|l|}{0} & \multicolumn{3}{|l|}{ C-* } & \multicolumn{3}{|l|}{ C-* } \\
\hline
\end{tabular}

Prenylated compounds were added to the incubation media from a stock solution using ethanol/water (1\%) as the solvent. The percentage of inhibition of mycelial growth is based on mycelium area measurements after $72 \mathrm{~h}$ of incubation. Each point represents the mean of at least three independent experiments. ${ }^{*} \mathrm{C}+$ refers to the positive control ( ${ }^{\mathrm{a}}$ captan at $100 \mu \mathrm{M}$ and ${ }^{\mathrm{b}}$ metalaxyl at $75 \mu \mathrm{M}$ ) and $\mathrm{C}-$ refers to the negative control and corresponds to stock solution with solvent (1\% aqueous ethanol).

The prenylated compounds showed statistically significant growth inhibition of Gibberella fujikuroi with high percentages of inhibition $72 \mathrm{~h}$ post inoculation at 250,500 and $1000 \mu \mathrm{M}$ with respect to fungal growth (negative control).

The results with $P$. cinnamomi showed that at the lowest concentration $(250 \mu \mathrm{M})$ none of the compounds were able to inhibit growth of this fungus (with the exception of $\mathbf{1 5}$, causing $100 \%$ inhibition at all concentrations), but compounds $\mathbf{1 2}$ and $\mathbf{1 3}$ inhibited the growth of $P$. cinnamomi to a greater extent than that of G. fujikuroi, at 500 and $1000 \mu \mathrm{M}$ (concentration-dependent effect). Compound 15 proved to be selective for P. cinnamomi and G. fujikuroi at lower concentrations $(250$ and $500 \mu \mathrm{M})$.

Table 1 shows that $B$. cinerea was the most resistant to the treatment with the prenylated compounds.

Compound $\mathbf{1 2}$ stands out among the compounds tested because it exhibits a high capacity to inhibit the growth of the three fungi, in high percentages, even exceeding $80 \%$ in some cases. Conversely, compound $\mathbf{1 1}$ shows the lowest antifungal activity of those recorded for the acetophenone group; however, 11 showed statistically significant inhibition activity though only towards $G$. fujikuroi.

The results of the antibacterial activity assays showed that all the prenylated compounds were able to inhibit in vitro growth of the three strains of bacteria tested (Table 2). Remarkably, most of the compounds significantly inhibited the growth of all three bacterial species in high percentages. Compound $\mathbf{1 1}$ showed lower but not negligible inhibition values. This was corroborated by calculating the $\mathrm{IC}_{50}$ values for each compound according to the bacteria tested (Table 3). Statistical analysis revealed that the inhibition values obtained are significant $(\mathrm{P}<0.05)$ compared to the negative control. 
Table 2. Percentage of inhibition of bacterial growth in the presence of prenylated compounds.

\begin{tabular}{|c|c|c|c|c|c|c|}
\hline \multirow[b]{2}{*}{ Concentration } & \multicolumn{6}{|c|}{ Percentage of inhibition of bacterial growth } \\
\hline & 1 & 11 & 12 & 13 & 14 & 15 \\
\hline$(\mu \mathrm{M})$ & \multicolumn{6}{|c|}{ A. tumefaciens } \\
\hline 250.0 & $81.5 \pm 0.25$ & $49.9 \pm 0.03$ & $89.8 \pm 0.05$ & $95.0 \pm 0.21$ & $90.6 \pm 0.15$ & $56.5 \pm 0.05$ \\
\hline 125.0 & $77.3 \pm 0.15$ & $42.4 \pm 0.05$ & $76.2 \pm 0.21$ & $87.5 \pm 0.25$ & $81.5 \pm 0.25$ & $57.3 \pm 0.15$ \\
\hline 62.5 & $70.5 \pm 0.11$ & $40.9 \pm 0.03$ & $71.4 \pm 0.25$ & $86.0 \pm 0.32$ & $62.8 \pm 0.33$ & $50.1 \pm 0.25$ \\
\hline 31.3 & $55.5 \pm 0.21$ & $38.7 \pm 0.15$ & $67.0 \pm 0.05$ & $46.0 \pm 0.15$ & $63.2 \pm 0.21$ & $48.4 \pm 0.21$ \\
\hline 15.6 & $52.4 \pm 0.25$ & $22.2 \pm 0.30$ & $63.8 \pm 0.01$ & $32.6 \pm 0.33$ & $54.7 \pm 0.21$ & $43.1 \pm 0.03$ \\
\hline 7.8 & $46.4 \pm 0.03$ & $18.6 \pm 0.25$ & $49.4 \pm 0.21$ & $11.3 \pm 0.15$ & $31.2 \pm 0.15$ & $25.4 \pm 0.05$ \\
\hline 3.9 & $19.2 \pm 0.21$ & $0.7 \pm 0.82$ & $42.8 \pm 0.05$ & $9.4 \pm 0.11$ & $30.1 \pm 0.21$ & $24.8 \pm 0.03$ \\
\hline$(\mu \mathrm{M})$ & \multicolumn{6}{|c|}{ P. syringae } \\
\hline 250.0 & $83.8 \pm 0.62$ & $77.9 \pm 0.05$ & $84.8 \pm 0.21$ & $85.1 \pm 0.65$ & $87.2 \pm 0.71$ & $88.6 \pm 0.05$ \\
\hline 125.0 & $79.5 \pm 0.71$ & $71.3 \pm 0.05$ & $74.7 \pm 0.33$ & $76.2 \pm 0.65$ & $81.1 \pm 0.75$ & $86.7 \pm 0.05$ \\
\hline 62.5 & $76.3 \pm 0.66$ & $71.7 \pm 0.05$ & $76.3 \pm 0.21$ & $69.9 \pm 0.21$ & $79.9 \pm 0.65$ & $79.2 \pm 0.23$ \\
\hline 31.3 & $62.8 \pm 0.05$ & $72.0 \pm 0.03$ & $73.3 \pm 0.03$ & $69.0 \pm 0.21$ & $70.0 \pm 1.25$ & $76.3 \pm 0.52$ \\
\hline 15.6 & $62.0 \pm 0.08$ & $66.3 \pm 0.25$ & $70.8 \pm 0.05$ & $65.0 \pm 0.05$ & $68.4 \pm 0.05$ & $76.7 \pm 0.025$ \\
\hline 7.8 & $62.6 \pm 0.11$ & $59.9 \pm 0.33$ & $65.3 \pm 0.21$ & $63.5 \pm 0.25$ & $65.5 \pm 0.05$ & $70.3 \pm 0.05$ \\
\hline 3.9 & $60.8 \pm 0.03$ & $49.3 \pm 0.66$ & $58.7 \pm 0.25$ & $62.6 \pm 0.21$ & $62.5 \pm 0.05$ & $65.3 \pm 0.05$ \\
\hline$(\mu \mathrm{M})$ & \multicolumn{6}{|c|}{ E. carotovora } \\
\hline 250.0 & $84.0 \pm 0.85$ & $68.4 \pm 0.23$ & $89.0 \pm 0.55$ & $90.4 \pm 0.25$ & $94.8 \pm 0.25$ & $85.4 \pm 0.21$ \\
\hline 125.0 & $70.2 \pm 1.25$ & $52.5 \pm 0.21$ & $68.0 \pm 0.25$ & $84.5 \pm 0.05$ & $72.9 \pm 0.05$ & $65.7 \pm 0.21$ \\
\hline 62.5 & $69.8 \pm 0.25$ & $52.5 \pm 0.21$ & $63.5 \pm 0.55$ & $80.2 \pm 0.05$ & $67.4 \pm 0.21$ & $65.7 \pm 0.05$ \\
\hline 31.3 & $69.2 \pm 0.25$ & $43.2 \pm 0.05$ & $61.6 \pm 0.21$ & $74.4 \pm 1.23$ & $57.4 \pm 0.21$ & $65.2 \pm 1.05$ \\
\hline 15.6 & $64.7 \pm 0.05$ & $36.6 \pm 1.25$ & $58.7 \pm 0.15$ & $71.8 \pm 1.25$ & $51.5 \pm 0.05$ & $64.3 \pm 1.05$ \\
\hline 7.8 & $63.5 \pm 0.25$ & $39.7 \pm 1.25$ & $56.5 \pm 0.10$ & $66.3 \pm 1.25$ & $49.2 \pm 0.05$ & $51.8 \pm 0.05$ \\
\hline 3.9 & $40.6 \pm 1.55$ & $40.9 \pm 2.55$ & $50.4 \pm 0.05$ & $67.7 \pm 2.55$ & $48.7 \pm 0.25$ & $48.7 \pm 0.05$ \\
\hline
\end{tabular}

Prenylated compounds were added to the incubation media from a stock solution using ethanol/water (1\%) as the solvent. The percentage of inhibition of bacterial growth is based on optical density $\left(\mathrm{OD}_{595 \mathrm{~nm}}\right)$ measurements after $7 \mathrm{~h}$ of incubation. Each point represents the mean of at least four independent experiments. $\mathrm{C}+$ (data not shown) refers to the positive control (streptomycin, $5 \mu \mathrm{M}$ ) which showed $100 \%$ inhibition in all cases; and $\mathrm{C}-$ refers to the negative control and corresponds to stock solution with solvent ( $1 \%$ aqueous ethanol) $(100 \%$ bacterial growth, data not shown).

Table 3. $\mathrm{IC}_{50}$ values of prenylated compounds against phytopathogenic bacteria.

\begin{tabular}{|c|c|c|c|}
\hline & & $\mathbf{I C}_{\mathbf{5 0}}(\boldsymbol{\mu M})$ & \\
\hline Compound & A. tumefaciens & P. syringae & E. carotovora \\
\hline $\mathbf{1}$ & $14.26 \pm 0.08$ & $<3.9$ & $5.62 \pm 0.11$ \\
\hline $\mathbf{1 1}$ & $250.00 \pm 0.13$ & $5.59 \pm 0.25$ & $54.21 \pm 1.02$ \\
\hline $\mathbf{1 2}$ & $7.99 \pm 0.25$ & $<3.9$ & $\leq 3.9$ \\
\hline $\mathbf{1 3}$ & $32.27 \pm 0.09$ & $<3.9$ & $<3.9$ \\
\hline $\mathbf{1 4}$ & $14.00 \pm 0.11$ & $<3.9$ & $9.91 \pm 1.05$ \\
\hline $\mathbf{1 5}$ & $62.5 \pm 0.13$ & $<3.9$ & $5.50 \pm 0.08$ \\
\hline
\end{tabular}

Antibacterial activities are shown as $\mathrm{IC}_{50}$ values in $\mu \mathrm{M}$ concentrations \pm $\mathrm{SD} . \mathrm{IC}_{50}$ values were calculated from the first kinetic assay. Positive control corresponds to streptomycin $(5 \mu \mathrm{M})$. 
The $\mathrm{IC}_{50}$ values indicate that the bacteria tested have different levels of sensitivity to the compounds tested. The most sensitive bacterial species was $P$. syringae, and the most resistant one was $A$. tumefaciens. This behavior informs us not only about the origin of each strain and its possible domestication in the laboratory, but also about different mechanisms of action of each compound on the pathogen tested, considering that the three bacteria tested have a similar membrane organization (Gram-negative).

After the first kinetic assay, the bactericidal capacity of each of the compounds was evaluated in a second growth kinetic assay using an inoculum from the first kinetics plate. This new culture was incubated for 7 hours, and the absorbance was measured. As a result, it was noted that the bacterial culture was able to recover its growth rate (with respect to the culture without the compound) to an extent between 50 to $85 \%$. This means that the antibacterial effect observed with some compounds corresponds to a bacteriostatic effect at the concentrations tested, or it can be assumed that the MBC value for all compounds is greater than $250 \mu \mathrm{M}$ (the highest concentration tested in the assay).

Compounds 11, 13 and 15 showed outstanding selectivity against $P$. syringae and to a lesser extent E. carotovora.

\subsection{DPPH radical scavenging activity}

The results obtained from the antioxidant activity assays are shown in Table 4. All the compounds were compared with trolox. Compound 9 was the only active precursor. The prenylated benzaldehyde $\mathbf{1 5}$ has an antioxidant activity close to the $\mathrm{IC}_{50}$ value of trolox. The prenylated acetophenone $\mathbf{1 2}$ is half as potent as trolox and $\mathbf{1 5}$. The presence of a carbonyl group attached to the benzene ring resulted in a decrease of the antioxidant activity with respect to the compounds without this group, but the presence of a prenyl group improved the antioxidant activity. This effect had already been observed in our previous work ${ }^{35}$.

Table 4. Screening results of DPPH radical scavenging activity of precursors 4-9 and prenylated derivatives 1, 11-15.

\begin{tabular}{|c|c|c|c|}
\hline Compound & $\mathbf{I C}_{\mathbf{5 0}} \boldsymbol{\mu M} \pm \mathbf{S D}$ & Compound & $\mathbf{I C}_{\mathbf{5 0}} \boldsymbol{\mu M} \pm \mathbf{S D}$ \\
\hline $\mathbf{4}$ & $\mathrm{NA}$ & $\mathbf{1}$ & $\mathrm{NA}$ \\
\hline $\mathbf{5}$ & $>100$ & $\mathbf{1 1}$ & $>100$ \\
\hline $\mathbf{6}$ & $>100$ & $\mathbf{1 2}$ & $50.44 \pm 0.59$ \\
\hline $\mathbf{7}$ & $\mathrm{NA}$ & $\mathbf{1 3}$ & $\mathrm{NA}$ \\
\hline $\mathbf{8}$ & $\mathrm{NA}$ & $\mathbf{1 4}$ & $\mathrm{NA}$ \\
\hline $\mathbf{9}$ & $87.05 \pm 1.77$ & $\mathbf{1 5}$ & $27.20 \pm 0.62$ \\
\hline Trolox & $22.60 \pm 0.25$ & & \\
\hline
\end{tabular}

Antioxidant activity is shown as $\mathrm{IC}_{50}$ values in $\mu \mathrm{M}$ concentrations; $\mathrm{NA}=$ no activity; $>100=\mathrm{IC}_{50}$ value over $100 \mu \mathrm{M}$. All compounds were analyzed in triplicate and the results expressed as average \pm standard deviation.

\section{CONCLUSIONS}

We have developed a one-step synthesis of prenylated acetophenone and benzaldehyde derivatives using $\mathrm{ZnCl}_{2}$ as a Lewis acid catalyst in ethyl acetate. This methodology does not require complex reaction conditions and has a relatively simple work-up procedure and good yields based on unrecovered aromatic starting material.

Prenylation affects the properties of the basic skeletons. Prenylated acetophenone and benzaldehyde derivatives could serve as useful compounds for the development of alternative antimicrobial pesticides.

We found that benzaldehyde $\mathbf{1 5}$ with catecholic hydroxyl groups had an $\mathrm{IC}_{50}$ value of $27.20 \mu \mathrm{M}$ close to Trolox's $\mathrm{IC}_{50}$ value. Thus, this type of substitution should be considered to synthesize antioxidant compounds. The introduction of a prenyl group increases the radical scavenging activity of the precursors 6 and 9.

Among the tested pathogens, P. syringae and G. fujikuroi were the most sensitive to the synthesized compounds. Among the compounds tested, compound $\mathbf{1 5}$ stands out for its antimicrobial capacity with inhibition percentages close to $89 \%(250 \mu \mathrm{M})$ and $100 \%(1000 \mu \mathrm{M})$, respectively.

\section{ACKNOWLEDGEMENTS}

The authors acknowledge support by FONDECYT (grant No. 1130924) and the Dirección General de Investigación, Innovación y Postgrado (DGIIP) of the Universidad Técnica Federico Santa María.

\section{Supplementary Material}

Request for supplementary information to the corresponding author, mauricio.osorio@usm.cl

\section{REFERENCES}

1. N. Edayadulla, P. A. Ramesh, Nat. Prod. Commun. 7, 1325 (2012)

2. M.E. Sánchez-Mendoza, J. Rodríguez-Silverio, J.F. Rivero-Cruz, H.I. Rocha-González, J.B. Pineda-Farías, J. Arrieta, Fitoterapia 87, 11 (2013)

3. B. Sontag, N. Arnold, W. Steglich, T. Anke, J. Nat. Prod. 62, 1425 (1999)

4. R.K. Mayaka, M.K. Langat, J.O. Omolo, P.K. Cheplogoi, Planta Med. 78, 383 (2012)

5. E. Jiménez, F. Dorta, C. Medina, A. Ramírez, I. Ramírez, H. Peña-Cortés, Mar. Drugs 9, 739 (2011).

6. W. El Khoury, K. Makkouk, J. Plant Pathol., 92 (4, Supplement), S4.35 (2010)

7. B. Williamson, B. Tudzynski, P. Tudzynski, J.A.L. Van Kan, Mol. Plant Pathol. 8, 561 (2007)

8. E.G. Wulff, J.L. Sørensen, M. Lübeck, K.F. Nielsen, U. Thrane, J. Jan Torp, Environ. Microbiol. 12, 649 (2010)

9. G. Sepúlveda-Chavera, R. Salvatierra-Martínez, C. Bilbao-Apata, P. Sepúlveda-Ramírez, M. Allende-Castro, J. Alache-González, IDESIA (Chile), 31, 41 (2013)

10. L. Gallo, F. Siverio, A.-M. Rodríguez-Pérez, Ann. Appl. Biol. 150, 65 (2007)

11. Ozone Secretariat United Nations Environment Programme (UNEP), Handbook for the Montreal Protocol on Substances that Deplete the Ozone Layer, $8^{\text {th }}$ ed.; Secretariat for The Vienna Convention for the Protection of the Ozone Layer \& The Montreal Protocol on Substances that Deplete the Ozone Layer: Nairobi, Kenya, 2009; pp. 291-292.

12. CODEX ALIMENTARIUS International Food Standards. http://www. codexalimentarius.org/about-codex/en/. (accessed on 26 January 2016).

13. M. Guo, A. Block, C.D. Bryan, D.F. Becker, J.R. Alfano, J. Bacteriol. 194, 5054 (2012)

14. R. Prajapat, A. Marwal, P.N. Jha, Int. J. Curr. Microbiol. App. Sci. 2, 83 (2013)

15. L.W. Moore, J.W. Pscheidt, Diseases Caused by Pseudomonas syringae. http://pnwhandbooks.org/plantdisease/node/1814/print. (accessed on 26 January 2016)

16. C. Hoarau, T.R.R. Pettus, Synlett 1, 127 (2003)

17. O Talhi, A.M.S. Silva, Curr. Org. Chem. 17, 1067 (2013)

18. S.R. Ravada, L.R. Emani, M.R. Garaga, B. Meka, T. Golakoti, Am. J. Infect. Dis. 5, 83 (2009)

19. S.N. Fedorov, O.S. Radchenko, L.K. Shubina, N.N. Balaneva, A.M. Bode, V.A. Stonik, Z. Dong, Pharm. Res. 23, 70 (2006)

20. Z. Wang, Y. Cao, S. Paudel, G. Yoon, S.H. Cheon, Arch. Pharm. Res. 36, 1432 (2013).

21. J.-J. Helesbeux, O. Duval, D. Guilet, D. Séraphin, D. Rondeau, P. Richomme, Tetrahedron 59, 5091 (2003)

22. M.P. Neves, R.T. Lima, K. Choosang, P. Pakkong, M. de S.J. Nascimento, M.H. Vasconcelos, M. Pinto, A.M.S. Silva, Cidade, H. Chem. Biodivers. 9, 1133 (2012)

23. X. Dong, Y. Wang, T. Liu, P. Wu, J. Gao, J. Xu, B. Yang, Y. Hu, Molecules 16, 8257 (2011)

24. A.C. Jain, R.C. Gupta, P.D. Sarpal, Tetrahedron 34, 3563 (1978)

25. V.P. Pathak, R.N. Khanna, Bull. Chem. Soc. Jpn. 55, 2264 (1982)

26. W. Reininger, A. Hartl, Method of acylation of phloroglucinol. US patent 4,053,517, filed 5 May 1976, issued 11 October 1977.

27. D. Ahmed, M.M. Khan, R. Saeed, Antioxidants 4, 394 (2015)

28. T.P.T. Cushnie, A.J. Lamb, Int. J. Antimicrob. Agents 38, 99 (2011)

29. M. Daglia, Curr. Opin. Biotechnol. 23, 174 (2012)

30. H. Naeimi, A. Amini, M. Moradian, Org. Chem. Front. 1, 415 (2014)

31. E. Bálint, O. Kovács, L. Drahos, Keglevich, G. Lett. Org. Chem. 10, 330 (2013) 
32. M. Vandewalle, Bol. Soc. Chim. Belg. 70, 163 (1961)

33. S. Alam, J. Miah, A. Islam, J. Biol. Sci. 4, 527 (2004)

34. L.Y. Zhao, Y.L. Li, Chin. Chem. Lett. 5, 1009 (1994)

35. M. Osorio, J. Aravena, A. Vergara, L. Taborga, E. Baeza, K. Catalán, C. González, M. Carvajal, H. Carrasco, L. Espinoza, Molecules 17, 556 (2012)

36. M.D. Cole, Biochem. Syst. Ecol. 22, 837 (1994)

37. I.C. Zampini, M.A. Vattuone, M.I. Isla, J. Ethnopharmacol. 102, 450 (2005)

38. P. Cos, A.J. Vlietinck, D.V. Berghe, L. Maes, J. Ethnopharmacol. 106, $290(2006)$

39. P.S. McManus, V.O. Stockwell, G.W. Sundin, A.L. Jones, Ann. Rev. Phytopathol. 40, 443 (2002).

40. S. Riggoti, K. Gindro, H. Richter, O. Viret, FEMS Microbiol. Lett. 209, $169(2002)$

41. T. Bekker, N. Labuschagne, C. Kaiser, S. Afr. Avocado Grow. Assoc. Yearb 28, 60 (2005)
42. M. Horta, N. Sousa, A.C. Coelho, D. Neves, A. Cravador, Physiol. Mol. Plant Pathol. 73, 48 (2008)

43. M. Azor, J. Gené, J. Cano, D.A. Sutton, A.W. Fothergill, M.G. Rinaldi, J. Guarro, Antimicrob. Agents Chemother. 52, 2228 (2008)

44. R. Salzman, I. Tikhonova, B. Bordelon, P. Hasegawa, R. Bressan, Plant Physiol. 117, 465 (1998)

45. S.I. Kirubakaran, S.M. Begum, K. Ulaganathan, N. Sakthivel, Plant Physiol. Biochem. 46, 918 (2008)

46. G. Zhu, F. Huang, L. Feng, B. Qin, Y. Yang, Y. Hen, X. Lu, Agric. Sci. China 7, 831 (2008)

47. M. Meepagala, G. Sturtz, G. Wedge, J. Agric. Food Chem. 50, 6989 (2002)

48. H. Alizadeh, A. Sharifi-Tehrani, G. Hedjaroude, Agric. Appl. Biol. Sci. 72, 795 (2007)

49. W. Steck, Can. J. Chem. 49, 1197 (1971) 